\title{
Assessing Conformity of Scientific Voices and Local Needs to Combat Forest Fire in Indonesia
}

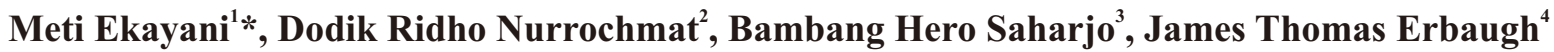

\author{
${ }^{1}$ Department of Resource and Environmental Economics, Faculty of Economics and Management, Bogor Agricultural \\ University, Campus IPB Dramaga, Bogor, Indonesia 16680 \\ ${ }^{2}$ Department of Forest Management, Faculty of Forestry, Bogor Agricultural University, Academic Ring Road, Campus IPB \\ Dramaga, PO Box 168, Bogor, Indonesia 16680 \\ ${ }^{3}$ Department of Silviculture, Faculty of Forestry, Bogor Agricultural University, Academic Ring Road, Campus IPB Dramaga, \\ Bogor, Indonesia 16680 \\ ${ }^{4}$ School of Natural Resources and Environment, University of Michigan, Ann Arbor, USA, 48109-1041
}

Received March 5, 2015/Accepted August 13, 2015

\begin{abstract}
This study evaluates the compatibility of scientific voices with the needs to combat forest fire as perceived by relevant stakeholders through a review of scholarly output, an evaluation of the conformity between scientists and stakeholder views on forest fire issues, and an analysis of how different types of scientists and voice channels contribute the local needs to combat forest fire in Indonesia. This research indicates that although forest fire has cross-country border impacts, forest fire discourses were dominated by home country issues rather than the concerns of global forest fire events. Further, although information about forest fire is widely available in the scientific journals, the "knowledge utilization" of this information remains low. To improve "knowledge utilization", scientists can use different channels to disseminate information, in addition to scientific journals. While socialeconomic aspects are perceived to be the prime problem of forest fire in Indonesia, the minimal presentation of social scientists within forest fire discourse is a concern. To address these primary concerns within and outside scientific journals, the involvement of social scientists within the forest fire discourse is very important.
\end{abstract}

Keywords: content analysis, forest fire, Indonesia, power analysis, scientific discourse

*Correspondenceauthor,email:metieka@yahoo.com,meti@ipb.ac.id,tel.: +62-251-8627868

\section{Introduction}

Indonesia, a tropical country in Southeast Asia with the majority of its land area covered by rain forest (Nurrochmat 2005; Marwa et al. 2010), experiences one of the most frequent forest fires in the world (Narendran 2001). Due to their high frequency and prevalence throughout the archipelago, it is extremely difficult to address and ameliorate the effects of forest fires across Indonesia (Goldammer 1998; Saharjo \& Munoz 2005; Goldammer \& Seibert 2008; Syaufina 2008); further, these fires often causes wide-ranging, international impacts (Nurrochmat et al. 2012; Gaveau et al. 2014; Ekayani et al. 2015). Forest degradation and repeated fires have led to the establishment of fire climax grasslands, with low productivity and frequent interval fires. Severe problems of environmental degradation such as erosion, loss of nutrients, disturbance of vegetation, and smoke and haze are the consequences of fires in these forests (Goldammer 1998; Saharjo \& Munoz 2005; Goldammer \& Seibert 2008; Syaufina 2008).

Public discourse in media, including scientific publications, can play a role in influencing policy agenda setting (Ekayani 2011; Kleinschmit 2012; Wibowo \&
Giessen 2012; Sadath \& Krott 2013; Ekayani et al. 2015). The voices of scientist, which are represented by scientific journals, can increase public awareness and potentially influence policy related to forest fire (Pielke 2007; Nurrochmat et al. 2010; Darusman 2012). According to Krott (2005), who writes about the importance of providing reliable information to improve the quality of policy, the task of providing high quality information by scientists to the public is best accomplished through publication in scientific journals. Forest fire is of great interest to scientific communities across international and national levels because of its far-reaching impacts. Despite this international interest, forest fire is most often discussed in scholarly and non-scholarly communities within countries directly impacted by forest fires, including Indonesia. From these discussions, policymakers receive information on how to address forest fires (Ekayani 2014). Therefore, scientists should perform an active role to help decision-makers identify the causes of forest fire and find the best options for combating or minimizing forest fire in Indonesia. This study evaluates the conformity of scientific contributions on forest fire issues and the local needs for combating forest fire, as perceived by relevant stakeholders, and the implication of 
this compatibility in the formulation of forest fire eradication policy in Indonesia. This research proceeds through three interrelated foci. First, we review the presentation of scientists from different fields within scholarly discourses on forest fire. Second, we evaluate the conformity of these scientific contributions and stakeholders relevant to forest fire issues; and third, we measure the power of scientists from different fields and alternative voice channels to address the quality of information for combating forest fire.

\section{Theoretical background}

The different types of scientists in influencing policy agenda-setting Scientists have the potential to influence policy agenda setting (Darusman 2012; Ekayani et al. 2015). Scientific voices can improve processes and results of decision making through the "use of knowledge" by policymakers (Dunn 2000). In addition to Dunn's argument, Krott (2005) argues that the reliability of information is very important in policy-making, because the quality of policy is strongly influenced by the quality of information. If political agenda setting, and politics in general, are series of communication activities (Roelofs in Nimmo 2004), then scientists can influence policy-making through direct communication with the public. According to Dunn (2000), "scientists" can influence the policy-process through "policy presentations", i.e. knowledge communication through interactive manners, including publication in public media, dialogues, conferences, meetings, and public hearings.

Pielke (2007) distinguished different types of scientists, as with the different role of political actors. As with Pielke's classification, Ekayani et al. (2015) and Sadath \& Krott (2013) argue that not all of scientists have the same influence in policy agenda-setting. Pielke (2007) classified four categories of scientists: first, a "pure scientist" has no interest in influencing the policy process and only seeks to share fundamental findings with other scientists. Second, a "science arbiter" serves as a resource for decision making, and answers factual questions that decision-makers consider relevant. Third, an "issue advocate", tries to convince decision-makers to make a particular decision, telling the decision-maker what he or she ought to prefer; and fourth, an "honest broker of policy alternatives" makes an effort to expand (or at least to clarify) the scope of choices and provides basic information on the different alternatives. As with Pielke (2007), Ekayani (2011) and Darusman (2012) illustrate that honest brokering of policy alternatives can be best achieved through a collection of experts, working together with a range of views, experiences, and knowledge.

Discourse as a policy analysis approach The term discourse is used within many disciplines, including linguistics, psychology, sociology, politics, communication, and literature (Eriyanto 2005). Discourse analysis emerged as a trans-disciplinary field of study in social sciences, concerned with the systematic study of the structures and functions of texts and talks (van Dijk 1989). As with van Dijk, Eriyanto (2005) argues that discourse analysis has three dimensions: text, social cognitive, and context. When studying the textual element of discourse, an analyst studies the structures and strategies within the written word to determine overall themes. When studying the social cognitive dimension of discourse, an analyst considers the process of making texts, which involves both individual and social cognition. Finally, when studying the dimension of contexts, an analyst studies the relationship between a particular discourse and the more general societal problem it is meant to address.

Eriyanto (2005) argues power is the central issue of analysis, and discourse can be used to enlarge and strengthen this power. According to Weberian thought, power is defined as the probability with which one can successfully assert one's own will against that of one's opposition within a social relationship (Park 2009). Each actor or group in a society, including scientists, has a different power in influencing policy process (Wibowo \& Giessen 2012; Sadath \& Krott 2013). It is also important to note that discourse can be manipulated by dominant groups in a society to meet their own interests. The stronger an individual's or a group's power, the more able it is to select and influence discourse (Eriyanto 2005; Ekayani 2011; Ekayani et al. 2015; ).

Power, interest, and influence of different types of scientist in policy process Krott (2005) holds that, in fact, stakeholders and political players both avail themselves of power. In practice, "power is a factor that comes in many forms and is often concealed where it is strongest-the powerful do not need loud voices. Power resists scientific analysis; all other aspects of forest policy are easier to discuss than that of power" (Krott 2005, p. 14).

According to Reed et al. (2009), interest and influence determine the power of actor in policy process. In policy science, interest is often considered one of the most important factors driving politics (Krott 2005; Nurrochmat et al. 2014; Ekayani et al. 2015; Sahide \& Giessen 2015; Sahide et al. 2015). Interest refers to the needs of all parties in achieving output and objectives (Reed et al. 2009). As with Abromeit (1993), Krott (2005) argues that interests generally constitute the cornerstone of modern social sciences and therefore, they play a major role in determining policy process. In addition to interest, influence refers to the power afforded by a party to control the process and results of a decision. Thus, how strong the power of an actor in policy process is depends on the cumulative results of his/her interest and influence in a particular matter.

\section{Methods}

Content analysis of selected journals The first step of this study included a content analysis of forest fire discourse within international and national scientific journals. We selected international journals from internationally recognized forestry journals. Following Real (2008), we selected among internationally recognized journals using four criteria. First, we gathered Journal Impact Factors (JIFs) for each journal appearing in the section of forestry of the web of science within the decade that contained the most forest fires in Indonesian history (1994-2003). Second, we selected journals with English as the main language of publication, as English is considered the global language of science (Crystal 1997; Ammon 2001). Third, we selected journals that offer a wide selection of forestry science topics; 
consequently journals which focused on limited topics of forestry science were eliminated. Since these three criteria is more important for selection rather than the name of journal, then we consider to attribute the five selected international journals as "A", "B", "C", "D", and "E".

We also include 2 national journals to evaluate: "F", a scientific journal published by one of the largest higher education institutions of forestry in Indonesia, and " $G$ ", one of the national scientific journals published by the Ministry of Forestry $^{1}$ of the Republic of Indonesia. We selected these national journals based on their national readership, containing broad aspects of forest science, and publication history of more than 10 years.

After the selection of scientific journals, we conducted a content analysis. Content analysis enables researchers to include large amounts of textual information and systematically identify its properties. Referring to Bos and Tarnai (1999) texts (of those journals) are generally the exclusive subjects of content analysis. Content analysis relies upon categorization based on 5 essential requirements: first, categories adequately reflect the investigator's research question; second, categories are exhaustive; third, categories are mutually exclusive; fourth, categories are independent; and fifth, each category is derived from a single classification principle (Holsti 1969). In this study, we analyzed content using the following categories: first, "location of event"; then the statements in the article are divided into categories of "field of science of the speakers", "problem definition", "causes of problem", and "instruments of solution". We then move to examine asymmetries between the international and national journals. This study proceeds through the following framework (Figure 1).

Discourse and stakeholder analysis Following content analysis, we conducted a discourse analysis focused on the voices of scientist within international and national journals who define forest fire problems, and identify causes and solutions of these problems. In addition to discourse analysis of journal articles, we consider perceptions from stakeholders in international and national organizations

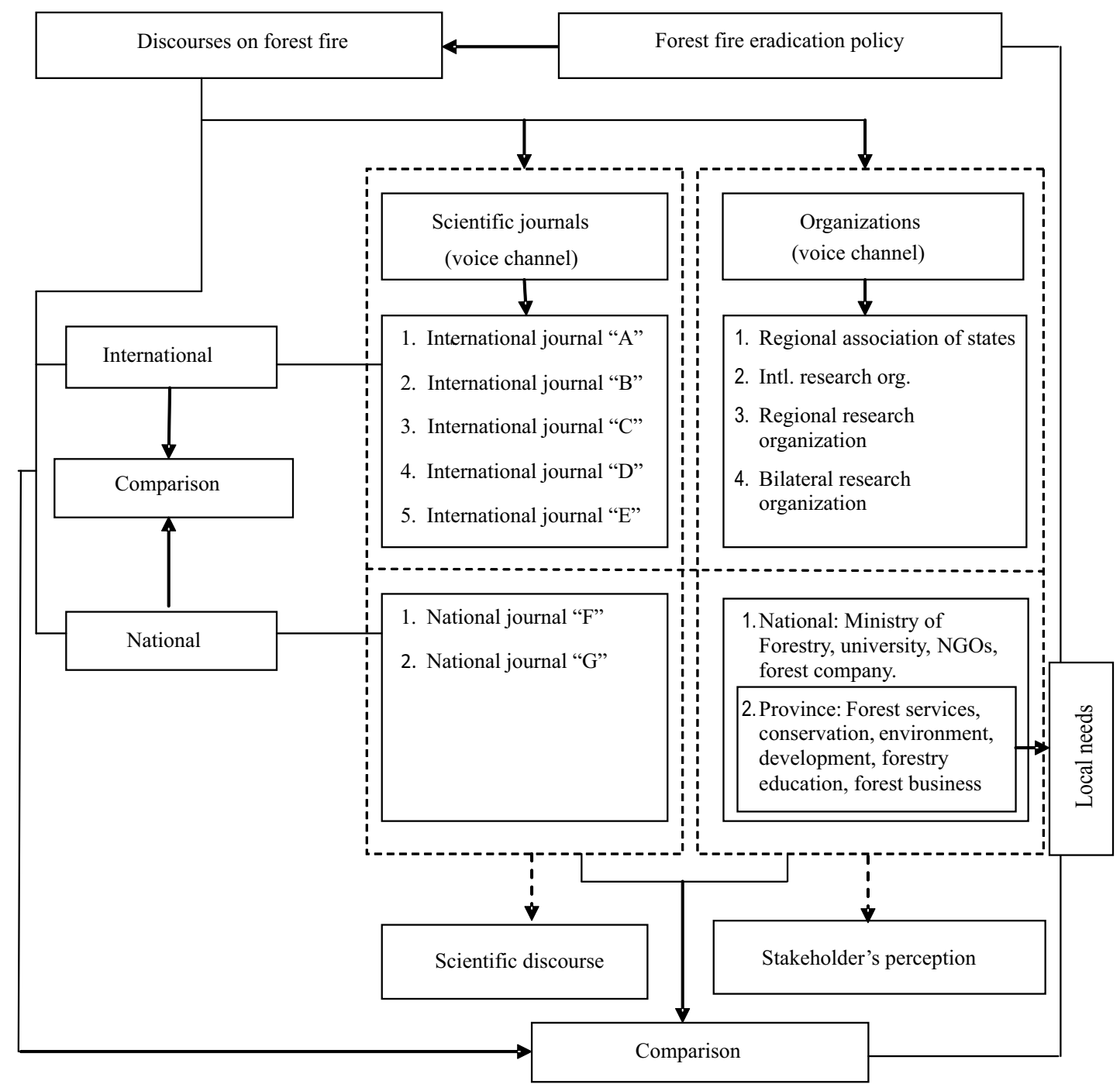

Figure 1 Study framework. 
concerned with forest fire issues. In total, we interviewed forty respondents. At the international organizations, we interviewed four respondents in total, with one each from the Center for International Forestry Research (CIFOR), ASEAN-Korea Cooperation Project (AKECOP), ASEAN Secretariat, and SEAMEO-BIOTROP. We conducted interviews with representatives from ASEAN institutions as they are highly relevant with forest fire issues in Indonesia. At the national level, interviews were conducted with twelve respondents in total, representing the Ministry of Forestry (6 respondents), scientists at Bogor Agricultural University (2), NGO activist (1), and forest enterprises (3). In local level, we conducted key-informant interviews with 24 respondents from a variety of organizations involved with forest services, conservation, environment, development, forestry education, and forest business. We selected those keyinformants from seven provinces, i.e. Riau (5 respondents), Bangka Belitung (3), West Java (4), D.I. Yogyakarta (3), East Kalimantan (4), Bali (2), and North Sulawesi (3) in order to represent the western, middle, and eastern geographical range of Indonesia and present local needs for combating forest fire according to the diversity of problems.

We compare the similarities and differences in reported forest fire problems, causes, and solutions between scientific publications and stakeholder perception and between international/national stakeholder perceptions with local stakeholders. We selected to use comparative analysis based on its ability to identify contradictions between multiple cases (Hartmann 1995). This study found contradictions between different sources of communication, namely scientific journals and organizations.

Power analysis As with Dunn (2000), Ekayani (2011) notes that there are several mediums, where scientists can use to enter public discourse, including news media, conferences, journals, or communication through organizations. This study focused on the evaluation of "power" of the scientific journals and organizations to address local needs for combating forest fire in Indonesia. We evaluate four different "channels" of communication within this study, including, "international journals", "national journals", "international organizations", and "national organizations".

Power has 2 elements: influence and interest (Reed et al. 2009). We evaluate the influence of a scientist to address the needs of forest fire eradication policy by comparing the conformity of the voices of scientists and the views of local stakeholders concerning forest fire. In this study, we analyzed the compatability between three aspects of forest fire discourse: problem definition, causes of problem, and instruments of solution. In addition to influence, we evaluate the interest of a particular channel by considering the country of the respective channel, its relation to forest fire, and its relation to forest fire in Indonesia.

Those scientists who can utilize publication and organization channels can be categorized into four different groups based on the relative amount of "power", or influence and interest, they contain (Reed et al. 2009). These different groups include:

1 "Key players", the active stakeholders, as they could afford high interest and high influence on the development of a particular matter.

2 "Context setters", the stakeholders who have high influence but exhibit a low interest;

3 "Subjects", the stakeholders who have high interest, but their influence is low; and

4 "Crowds", the stakeholders who have low interest and influence on the expected results.

This study assessed the compatibility of scientific input and local needs of forest fire eradication policy as determined by stakeholder's perception. It is assumed that the local needs are represented by perceptions of stakeholder in the site level. The steps of this analysis are described in the Figure 2.

\section{Results and Discussion}

Presentation of different fields of scientist in forest fire scientific discourses This study analyzed 68 articles and 2,873 statements on forest fire from five international journals. This includes 42 articles and 132 statements from the international journal " $A$ ", 41 articles and 1,909 statements from "B", 2 articles and 68 statements from " $C$ ", 2 articles and 50 statements from the "E", and 0 articles or statements from " $\mathrm{D}$ ". Thus, of the five international journals under analysis, scientific discourse on forest fire proceeds mostly through "A" and "B", with little or no mention within the other three journals.

Looking at the scale of content, most of the articles on forest fire that were published in international journals had a "local" (47.06\%) or "national" focus (35.29\%). Only 5.88\% of forest fire articles in international journals had "global" or "regional" focus. Considering the country of focus within these selected international publications, nearly $80 \%$ of articles focused on events in the USA and Canada, with the remaining $20 \%$ of events also located within the Americas, including Bolivia, Brazil, and Mexico. None of the articles from the five international journals we analyzed discussed forest fires in Indonesia, despite destructive fires in 1997 and 1998 that resulted in the loss of significant tropical forest area.

The international scientific discourse often focuses on forest fire events occurring in or near the locations where international journals are published and the locations in which scientists live. More than $90 \%$ of the authors who contributed to publications on forest fire in the selected international journals are from the USA and Canada. According to their scientific backgrounds, most authors $(61 \%)$ coming from "hard" forest science ${ }^{2}$, with, the rest from natural and conservation sciences; not one social scientist published an article on forest fires within the five international journals we analyzed. This indicates that international journals we selected, which have the highest impact factor and reach of all forestry journals, mostly published articles on the technical aspects of forest fires rather than the social dimensions of forest fires.

In total, we reviewed 22 articles from Indonesian forestry journals. The national journal " $G$ " contained 14 articles and 107 statements on forest fire, while " $F$ " had 8 articles and 103 statements. Based on the scale or "scope of event", $45.45 \%$ of the discourse focused on the national scale, and $40.91 \%$ on the local scale. Considering the "country of event", almost 
all articles published in national journals took place in Indonesia, with one article also referring Malaysia. In both national journals ("F" and "G"), approximately $95 \%$ of the authors were associated with "hard" forest science, and 5\% were related to other natural sciences' background. All authors of forest fire articles within the Indonesian forestry journals were from mostly Indonesia and one from Thailand.

Comparing problem definitions, causes, and intruments of solution of forest fire among different channels This section compares the views of scientific journals with stakeholder perceptions from international, national, and local organizations concerning the definitions of forest fire problems, and the causes as well as the solutions to these problems. We find that, overall, international and national scientific journals define the environment to be of utmost concern with regard to forest fire problems. On the contrary, stakeholders from the international, national, and local organizations all found economic considerations to be the primary important to problem definition for forest fires. Stakeholders' perception in the international and national organizations about problem definition of forest fire conforms with the voice of local stakeholders.

Besides miscellaneous causes of forest fire, this research indicates that "accidental causes", such as the El-Niño phenomenon, climate, long drought, low rainfall, and lightning-ignited wildfire, are the most important causes of fire indicated in both international $(21.35 \%)$ and national $(20.59 \%)$ scientific journals. Some publications do mention "intentional" causes of forest fires $(3.95 \%$ international and
$5.88 \%$ national), such as forest conversion into farm land, or "inadvertent causes" (0.10\% international and $13.73 \%$ national) from human negligence, including local communities using fire to use to find honey and assist with wildlife hunting. The depiction of forest fire cause within scientific journals contrasts sharply with the different levels of stakeholder's perceptions. International, national, and local stakeholders identified deliberate factors or "intentional causes" as the primary drivers of forest fire.

"Praxis" was identified as the most commonly cited instruments to address problems of forest fire within scientific journals, international and national organizations, as well as local stakeholder perceptions. Although both scientific journals and organizations pointed to "praxis" as the most important solution in addressing forest fires, their emphases are different. All stakeholders in international and national organizations, as well as local stakeholders, agree that the most effective solution to prevent and combat forest fires is through the application of "zero burning" in land clearing activities. Furthermore, most stakeholders consider active community involvement in forest management an effective solution to prevent and overcome the problem of repeated forest fires in Indonesia. This view differs from scientific journals, which reference "praxis" instruments relating forest fire prevention efforts, including: planting fire resistant trees as fire breaks, applying better harvesting techniques, and using weather forecasting models to anticipate and address the problems of forest fires. In addition to "praxis", all stakeholders and scientific journals reference "regulative instruments" as an important solution

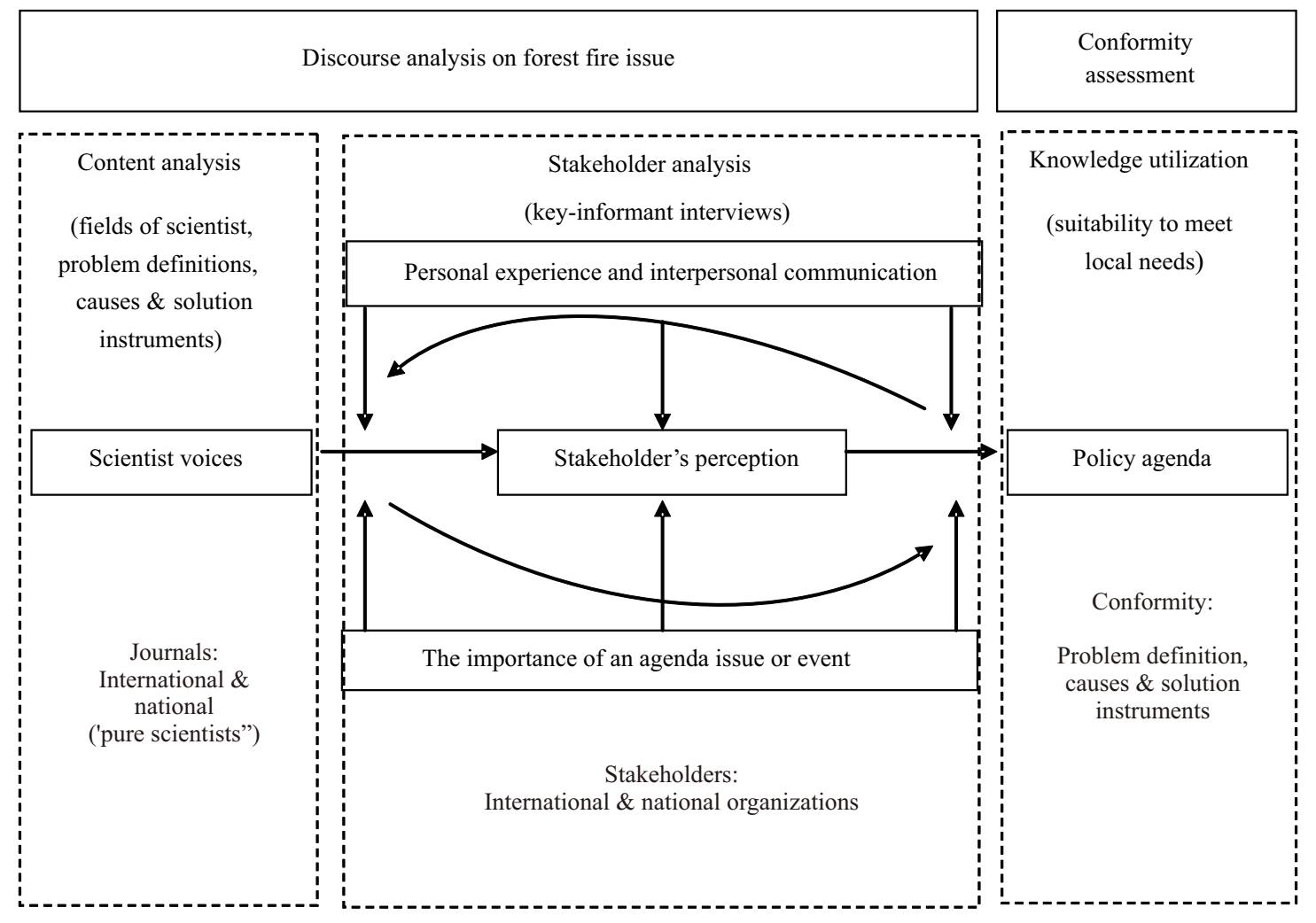

Figure 2 Steps of Analysis. 
that cannot be ignored to control, prevent, and combat forest fires in Indonesia. These "regulative instruments" include legal sanctions for those who break laws related to forest fires and perpetrate fire related crimes.

Power, position, and suitability of channels to deliver voices of scientist to meet local needs to combat forest fire in Indonesia As explained in the methodology, this study considers that interest, one of two core components of power, is reflected in the position of channels addressing forest fire in Indonesia. This includes the country of fire location, relation to a given forest fire issue, and relation to forest fires in Indonesia. Table 2 describes the potential interest of the respective channel to address local needs for combating forest fire in Indonesia.

As was discussed in the previous section, most of the articles on forest fire published in international journals focused on local and national scope. Looking at the country of event, none of the articles out of the five international journals discussed forest fires in Indonesia. This indicates that although those international forestry journals are interested in forest fire issues, they mostly do not meet local context of Indonesia nor address Indonesian forest fire problems, causes, or solutions. Thus, according to the description in the Table 2, the potential interest for international journals to contribute to local needs for combating forest fire in Indonesia is low. All other voice channels, however, have a high potential interest to assist in combating forest fire in Indonesia, since they address local context. In addition to the potential interest indicated in Table 2, it is also important to evaluate the potential influence of different channels to meet local needs to combat forest fire in Indonesia, as summarized in Table 3.

Table 3 indicates that the international and national journals have low influence on local needs for combating forest fire in Indonesia, since they hold different views in defining primary problem, causes, and solutions to forest fire as compared to local needs. Scientific journals indicate that forest fires are most often associated with environment concerns and "accidental" causes are the the most frequent origin of forest fires. Alternatively, stakeholders hold contrasting views. Stakeholders from international and national organizations, as well as local contexts, perceive that economic factors are the main problem related to forest fire, and that forest fire in Indonesia is most often has an "intentional" cause. Though different in emphasis, scientific publication and stakeholder perceptions all indicate that "praxis" is the most relevant instrument to combat forest fire in Indonesia. In sum, we find that the international and national organizations within this study have a greater potential to adress the needs to combat forest fire than the selected international and national scientific journals.

This study also indicates that the conformity of voices from scientific journals and the views of stakeholders is generally low. This finding shows that the "knowledge utilization" of scientific journals within the policy process in Indonesia-specifically the forest fire eradication policy - is low. Stakeholders in international and national organizations, however, can contribute relevant knowledge to the policy process much better than scientific voices in journals can. Consequently, the "knowledge utilization" of stakeholders from international and national organizations in influencing the policy process of forest fire eradication in Indonesia is relatively high. Dunn (2000) argues that utilization of useful knowledge by policy makers would improve policy processes and outcomes. Table 4 indicates that the "pure scientists" who use scientific journals as the only channel to deliver their voices have less influence in policy process. On the other hand, scientists more directly influence the policy process if they work in international or national organizations as so called "science arbiter" (Pielke 2007; Darusman 2012).

Referring to the power catogories of Reed et al. (2009), international journals are categorized as "crowd", with low interest and influence in reference to Indonesian forest fire concerns. In contrast to international journals, national journals contribute a higher interest for combating forest fire in Indonesia. As with international journals, scientists publishing in national journals largely come from "hard" forest science backgrounds, including silviculture and conservation biologists. These scientists often emphasize environmental aspects instead of social-economy dimensions. Since the local needs for combating forest fire in Indonesia are considered social-economy in nature, the influence of national journals to contribute to practical solutions of forest fire is also low. Therefore, power position of national journals is "subject" which have high interest but hold low influence in policy process of eradicating forest fire in Indonesia.

Different from "pure scientists", the "science arbiters" in international and national organizations are categorized as "key players", due to their high interest and influence. Thus, these potentially contribute to meet local needs for combating forest fire in Indonesia.

Table 1 Compatibility of scientific journals and stakeholders in international and national level to meet local needs of the local context on forest fire

\begin{tabular}{lccccc}
\hline \multirow{2}{*}{ Elements } & \multicolumn{2}{c}{ Scientific journals } & \multicolumn{2}{c}{ Stakeholders } & \multirow{2}{*}{ Needs in local context } \\
\cline { 2 - 4 } & International & National & International & National & \\
\hline Problem definition & Environment & Environment & Economy & Economy & Economy \\
Causes of problem & Accidental & Accidental & Intentional & Intentional & Intentional \\
Instruments of solution & Praxis & Praxis & Praxis & Praxis & Praxis \\
\hline
\end{tabular}

*This study assumed that the local needs are represented by perceptions of stakeholder in the site level (Province) 
Table 2 Potential interest of different channels to meet local needs to combat forest fire in Indonesia

\begin{tabular}{|c|c|c|c|c|c|c|c|}
\hline \multirow{3}{*}{ Voice channel } & \multicolumn{6}{|c|}{ Compatibility of the respective channel with site context } & \multirow{3}{*}{$\begin{array}{c}\text { Potential interest } \\
\text { of channel to meet } \\
\text { local needs }\end{array}$} \\
\hline & \multicolumn{2}{|c|}{ Country of location } & \multicolumn{2}{|c|}{$\begin{array}{c}\text { Relation with forest fire } \\
\text { issue }\end{array}$} & \multicolumn{2}{|c|}{$\begin{array}{l}\text { Relation with forest fire in } \\
\text { Indonesia }\end{array}$} & \\
\hline & $\begin{array}{l}\text { Respondent } \\
\text { channel }\end{array}$ & Site context & $\begin{array}{c}\text { Respondent } \\
\text { Channel }\end{array}$ & $\begin{array}{c}\text { Site } \\
\text { context }\end{array}$ & $\begin{array}{c}\text { Respondent } \\
\text { Channel }\end{array}$ & Site context & \\
\hline International journals & Abroad & Indonesia & Related & Related & Not related & Related & Low \\
\hline National journals & Indonesia & Indonesia & Related & Related & Related & Related & High \\
\hline International organization & Indonesia & Indonesia & Related & Related & Related & Related & High \\
\hline National organization & Indonesia & Indonesia & Related & Related & Related & Related & High \\
\hline
\end{tabular}

A channel has "high" interest to meet the needs of forest fire abatement if at least two elements of the forest fire discourse are identical with the site context and "low" if the conformity of elements between the particular channel and the site context is less than two.

Table 3 Potential influence of different channels to meet local needs to combat forest fire in Indonesia

\begin{tabular}{lccccc}
\hline & \multicolumn{2}{c}{$\begin{array}{c}\text { Possibility to influence the agenda of } \\
\text { forest fire eradication policy in } \\
\text { Indonesia }\end{array}$} & \multicolumn{2}{c}{$\begin{array}{c}\text { Possibility of voices to meet local needs to combat forest fire in } \\
\text { Indonesia }\end{array}$} \\
\cline { 2 - 6 } Voice channel & $\begin{array}{c}\text { Knowledge } \\
\text { utilization }\end{array}$ & $\begin{array}{c}\text { Major type of } \\
\text { scientist }^{2}\end{array}$ & $\begin{array}{c}\text { Level of } \\
\text { interest }^{3}\end{array}$ & $\begin{array}{c}\text { Level of influence } \\
\text { Power position }\end{array}$ \\
\hline International journals & Low & Pure scientist & Low & Low & Crowd \\
National journals & Low & Pure scientist & High & Low & Subject \\
International organizations & High & Science arbiter & High & High & Key player \\
National organizations & High & Science arbiter & High & High & Key player \\
\hline
\end{tabular}

A channel has "high" influence for meeting the needs of forest fire abatement if at least two elements of the forest fire discourse are same with the voices of local stakeholders and "low" if the conformity of elements between the particular channel and voices of local stakeholders is less than two.

Table 4 Potential of scientists to influence policy agenda setting and to meet local needs to combat forest fire in Indonesia in different voice channels

\begin{tabular}{|c|c|c|c|c|c|c|c|}
\hline \multirow{3}{*}{ Voice channel } & \multicolumn{6}{|c|}{ Compatibility of the respective channel with the voices of local stakeholders } & \multirow{3}{*}{$\begin{array}{c}\text { Potential } \\
\text { influence of } \\
\text { channel to meet } \\
\text { local needs }\end{array}$} \\
\hline & \multicolumn{2}{|c|}{ Problem definition } & \multicolumn{2}{|c|}{ Causes of problem } & \multicolumn{2}{|c|}{ Instruments of solution } & \\
\hline & $\begin{array}{c}\text { Respondent } \\
\text { Channel }\end{array}$ & $\begin{array}{c}\text { Local } \\
\text { stakeholders }\end{array}$ & $\begin{array}{c}\text { Respondent } \\
\text { Channel }\end{array}$ & $\begin{array}{c}\text { Local } \\
\text { stakeholders }\end{array}$ & $\begin{array}{c}\text { Respondent } \\
\text { channel }\end{array}$ & $\begin{array}{c}\text { Local } \\
\text { stakeholders }\end{array}$ & \\
\hline International journals & Environ & Economy & Accidental & Intentional & Praxis & Praxis & Low \\
\hline National journals & Environ & Economy & Accidental & Intentional & Praxis & Praxis & Low \\
\hline International organization & Economy & Economy & Intentional & Intentional & Praxis & Praxis & High \\
\hline National organization & Economy & Economy & Intentional & Intentional & Praxis & Praxis & High \\
\hline
\end{tabular}

${ }^{1}$ The term of "knowledge utilization" refers to Dunn (2000); ${ }^{2}$ The types of scientist refer to the classification of Pielke (2007); ${ }^{3}$ The level of interest refers to Table $2 ;{ }^{4}$ The level of influence refer to Table $3 ;{ }^{5}$ The power position refers to the category of Reed et al. (2009).

\section{Conclusion}

Though forest fire has cross-country border impacts, scientific discourse within the top international forestry journals less considered global forest fire issues across Southeast Asia, particularly Indonesia. The voices of authors in those journals addressed mostly national and local concerns within the home country of authors. Consequently, referring to the power categories, international journals could be categorized as "crowd" that indicates to play less important roles in contributing to the local needs for combating forest fire in Indonesia. For national journals, although they hold a high interest on forest fire issues in 
Indonesia, their influence to contribute local needs to combat forest fire is low, due to their incompatibily concerning problem definition, causes, and potential solutions to forest fire. Thus, according to Reed's category the national journal is positioned as "subject" who has high interest but less influence in forest fire eradication policy process. In addition to scientific journals, this study also indicates that the voices of international and national stakeholders conform to the stakeholder perceptions from a local context, which emphasizes increasing awareness and participation of people in forest and fire management. Thus, these organizations can be categorized as "key players" who can play an important role in contributing to the combating of forest fire in Indonesia. Finally, this study concludes that though plenty information about forest fire is available within scientific journals, the "knowledge utilization" of those journals for contributing to forest fire reduction in the local context of Indonesia is low.

\section{Recommendation}

This study recommends that to improve the "knowledge utilization" in forest fire issues, scientists should use more and different channels to communicate to the public. This might involve participating as a "science arbiter" through a particular organization, in addition to contributing views in scientific journals. This study also suggests that in addition to using multiple channels to deliver scientific findings, increasing the active involvement of social scientists in the scientific discourse arena on forest fire can also improve "knowledge utilization".

\section{Acknowledgment}

The first author would gratefully acknowledge to Professor Dr. Max Krott, Director of the Chair of Forest Policy and Nature Conservation, University of Goettingen, Germany, and Professor Dr. Daniela Kleinschmit for their most valuable academic inputs. The first author also expresses sincere gratitude to the International Tropical Timber Organizations (ITTO) and the Directorate General of Higher Education (DIKTI), Ministry of National Education of the Republic of Indonesia for the research funding. Finally, we are grateful to the Ministry of Environment and Forestry of the Republic of Indonesia and the line institutions for the most valuable data and information.

\section{References}

Abromeit H. 1993. Interessenvermittlung zwischen Konkurrenz und Konkordanz. Leske und Budrich, Opladen. http://dx.doi.org/10.1007/978-3-322-96029-0.

Ammon U. 2001. The Dominance of English as a Language of Science: Effects on Others Languages and Language Communities. Berlin: Mouton de Gruyter. http://dx.doi.org/10.1515/9783110869484.

Bos W, Tarnai C. 1999. Content analysis in empirical social research. International Journal Educational Research 31(8):659-671. http://dx.doi.org/10.1016/S08830355(99)00032-4.
Crystal D. 1997. English as a Global Language. Cambridge: Cambridge University Press.

Darusman D. 2012. Penggunaan Ilmu Pengetahuan di Indonesia: Refleksi dan Evaluasi. Kembali ke Jalan Lurus. In: Kartodihardjo, H. (Ed.). Kritik Penggunaan Ilmu dan Praktik Kehutanan Indonesia. Bogor: FORCI Development.

Dearing JW, Rogers EM. 1996. Agenda Setting. Sage, Thousand Oaks.

Dunn WN. 2000. Pengantar Analisis Kebijakan Publik (Public Policy Analysis: An Introduction). Yogyakarta: Gadjah Mada University Press.

Ekayani M. 2011. Comparison of discourses in global \& Indonesian media and stakeholders' perspectives on forest fire [dissertation]. Goettingen: University of Goettingen.

Ekayani M. 2014. Assymetric communication between media and stakeholders and its influences to the ineffectiveness of forest fire risk management in Indonesia. The XXIV IUFRO World Congress, Salt Lake City, USA 5-11 October 2014. Abstract. The International Forestry Review 16(5).

Ekayani M, Nurrochmat DR, Darusman D. 2015. The role of scientists in forest fire media discourse and its potential influence for policy-agenda setting in Indonesia. Forest Policy Economics In Press. http://dx.doi.org/ 10.1016/j.forpol.2015.01.001.

Eriyanto. 2005. Analisis Wacana. Pengantar Analisis Teks Media. Yogyakarta: LKIS.

Gaveau DLA, Salim MA, Hergoualc'h K, Locatelli B, Sloan S, Wooster M, Marlier ME, Molidena E, Yaen H, DeFries R, Verchot L, Murdiyarso D, Nasi R, Holmgren P, Sheil D. 2014. Major atmospheric emissions from peat fires in Southeast Asia during non-drought years: evidence from the 2013 Sumatran fires. Scientific Reports 4:6112, 1-7. http://dx.doi.org/10.1038/srep06112.

Goldamer JG. 1998. Environmental problems arising from land use, climate variability, fire and smog in Indonesia: Development of policies and strategies for land use and fire management. WMO Workshop on Regional Tran boundary Smoke and Haze in South-East Asia, Singapore.

Goldammer JG, Seibert B. 1989. Natural rain forest fires in eastern Borneo during the Pleistocene and Holocene. Naturwissenschaften 76:518-520. http://dx.doi.org/ 10.1007/BF00374124.

Hartmann J. 1995. Vergleichende Politikwissenschaft. Ein Lehrbuch. Frankfurt: Campus Verlag.

Holsti OR. 1969. Content Analysis for the Social Sciences and Humanities. Michigan: Addison-Wesley pub. 
Kleinschmit D. 2012. Confronting the demands of a deliberative public sphere with media constraints. Forest Policy Economics 16:71-80. http://dx.doi.org/10.1016/ j.forpol.2010.02.013.

Krott M. 2005. Forest Policy Analysis. Dordrecht: Springer.

Marwa J, Purnomo H, Nurrochmat DR. 2010. Managing the Last Frontier of Indonesian Forest in Papua. Bogor: AKECOP-IPB.

McQuail D, Windahl S, 1993. Communication Models for the Study of Mass Communication. London: Longman.

Narendran K. 2001. Forest fires origins and ecological paradoxes. Resonance 6(11):34-41.

Nimmo D. 2004. Komunikasi Politik. Komunikator, Pesan, dan Media. Bandung: PT. Remaja Rosdakarya.

Nurrochmat DR. 2005. Strategi Pengelolaan Hutan. Upaya Menyelamatkan Rimba yang Tersisa. Yogyakarta: Pustaka Pelajar.

Nurrochmat DR, Dharmawan AH, Obidzinski K, Dermawan A, Erbaugh JT. 2014. Contesting national and international forest regimes: Case of timber legality certification for community forests in Central Java, Indonesia. Forest Policy Economics. In Press. http://dx.doi.org/10.1016/j.forpol.2014.09.008.

Nurrochmat DR, Hasan MF, Suharjito D, Hadianto A, Ekayani M, Sudarmalik, Purwawangsa H, Mustaghfirin, Ryandi ED. 2012. Ekonomi Politik Kehutanan. Mengurai Mitos dan Fakta Pengelolaan Hutan. Jakarta: INDEF.

Park MS. 2009. Media Discourse in Forest Communication: The Issue of Forest Conservation in The Korean and Global Media. Goettingen: Cuvillier Verlag.

Pielke Jr RA. 2007. The Honest Broker. Making Sense of Science in Policy and Politics. New York: Cambridge University Press. http://dx.doi.org/10.1017/CBO97805 11818110

Real A. 2008. Discourses and distortions: dimensions of global and national forest science communication [dissertation]. Goettingen: University of Goettingen.

Reed SM, Graves A, Dandy N, Posthumus H, Huback K, Morris J, Prell CH, Quin CH, Stringer LC. 2009. Who's in and why? A typology of stakeholder analysis methods for natural resources management. Journal of Environmental Management 30:1-17. http://dx.doi.org/ 10.1016/j.jenvman.2009.01.001.

Sadath MN, Krott M. 2013. Can print media discourse drive forest policy change in Bangladesh? Journal of Sustainable Development 6(5):1-11. http://dx.doi.org/ 10.5539/jsd.v6n5p 1 .

Sahide MAK, Giessen L. 2015. The fragmented land use administration in Indonesia -Analysing bureaucratic responsibilities influencing tropical rainforest transformation systems. Land Use Policy 43 (2015):96-110. http://dx.doi.org/10.1016/j.landusepol. 2014.11.005.

Sahide MAK, Nurrochmat DR, Giessen L. 2015. The regime complex for tropical rainforest transformation: Analysing the relevance of multiple global and regional land use regimes in Indonesia. Land Use Policy 47 (2015); 408-425.

Saharjo BH, Munoz CP. 2005. Controlled burning in peat lands owned by small farmers: a case study in land preparation. Wetlands Ecology and Management 13:105-110. http://dx.doi.org/10.1007/s11273-0035110-z.

Syaufina L. 2008. Kebakaran Hutan dan Lahan di Indonesia: Perilaku Api, Penyebab, dan Dampak Kebakaran. Malang: Bayumedia Publishing.

van Dijk TA. 1989. Structure of Discourse and Structure of Power. In: Andersen, J.A, editor. Communication Year book 12. Sage: Newburg Park.

Wibowo A, Giessen L. 2012. Identifying international forest related issues in Indonesia based on actors' statements in public and expert deliberations. International Journal of Social Forestry 5(1):1-30.

Note:

' Under Mr. Joko Widodo presidency (2014-2019), the Ministry of Forestry is merged with the Ministry of Environment, named the Ministry of Environment and Forestry

${ }^{2}$ Hard science is any of the natural or physical sciences, as chemistry, biology, physics, or astronomy, in which aspects of the universe are investigated by means of hypotheses and experiments (http://dictionary. reference.com, downloaded 11/08/2015). Thus, the "hard forest science" means the hard science related with, or used in, forestry).

${ }^{3}$ Knowledge utilization means utilization of knowledge by decision makers in order to improve the process and results of decision-making (Dunn 2000). 